\title{
On the photographic action of electromagnetic waves
}

\section{Franz Von Dobrzynski}

To cite this article: Franz Von Dobrzynski (1891) On the photographic action of electromagnetic waves, Philosophical Magazine Series 5, 31:188, 75-75, DOI: 10.1080/14786449108620075

To link to this article: http://dx.doi.org/10.1080/14786449108620075

曲 Published online: 08 May 2009.

Submit your article to this journal $[\pi$

Џ Article views: 2

Q View related articles $\asymp$ 
passage from one to the other of the two extreme forms of the phenomenon does really take place.-Rendiconti della Reale Accademia dei Lincei, vol. iv. pp. 151, 189; Journal de Physique, Nov. 1890.

\section{ON THE PHOTOGRAPHIC ACTION OF ELECTROMAGNETIC WAVES. BY FRANZ VON DOBRZYNSKI.}

For several months $I$ have been engaged in investigating the photographic action of electromagnetic waves. On May 1 I observed an indication of this action, and on July 9 the action itself.

The electromagnetic waves were obtained by the metbod of Hertz. They acted on dry bromide of silver and gelatine 'Nys' plates procured from Geissler in Bonn.

The plane of the plates either included the axis of the vibrator or was at right angles to it. The exposure was three hours. No sensitization of the plates was made. The development and fixation took place in the ordinary manner by ferric oxalate and byposulphite.

The action was visible after development and fixation by the appearance of alternating bright and dark bands across the direction of vibration of the waves, or by the appearance of dark bands in the direction of the vibration. Both kinds of bands could occasionally be observed together.

In many experiments the plates were covered with tinfoil. Portions of the coating of the tinfoil were cut away. The tinfoil did not prevent the formation of bands. This points to the fact that the chemical action which here comes into play is not a primary one.

The cross bands suggested stationary vibrations. They might be due to reflexion from the sides of the wooden box, by which the plates were protected from the influence of extraneous rays; but they might also owe their origin to reflexion from the side of the room*.

The only experiment which could be made with a reflecting metal ball was not in disagreement with this view; the cross bands were now more distinct and regular.

If this view is correct, it may be concluded that waves of from 0.6 to 20 centim. are effective.

The complete description of the mode of experimenting I will defer until I communicate further investigations in this direction. -Wiener Berichte, October 9, 1890.

* The plates often contained two systems of cross bands. These would represent different waves which the vibrator emits in the sense of the discovery of Sarasin and De la Rive, and in that of the view stated above. 